\title{
Phytoremediating Batik Wastewater Using Vetiver Chrysopogon zizanioides (L)
}

\author{
Jenny Anna Margaretha Tambunan ${ }^{1 *}$, Hefni Effendi², Majariana Krisanti ${ }^{3}$ \\ ${ }^{1}$ Graduate Programme of Natural Resources and Environmental Management, Bogor Agricultural University, Indonesia \\ ${ }^{2}$ Centre for Enviromental Research, Bogor Agricultural University, Indonesia \\ ${ }^{3}$ Department of Aquatic Resources Management, Bogor Agricultural University, Indonesia
}

Received: 8 March 2017

Accepted: 30 August 2017

\begin{abstract}
Increased wastewater from the batik and textile industries as well as the content of chromium released from the coloring process will negatively affect an aquatic environment. The phytoremediation technique using Vetiver (Chrysopogon zizanioides L.) was applied to treat the wastewater. A hydroponic system with batik wastewater concentrations of $0 \%, 50 \%, 75 \%$, and $100 \%$ was selected. Each treatment contained six pots, and each pot consisted of three clumps. This study aimed to determine the ability of Chrysopogon zizanioides L. to decrease chromium concentrations and improve water quality parameters (Ammonia, BOD, and COD) and analyze Chrysopogon zizanioides L. growth. On 50\% wastewater composition, removal efficiency of chromium was $40 \%$, BOD was $37.95 \pm 8.14 \mathrm{mg} / \mathrm{L}$, removal efficiency of BOD was $98.47 \%$, COD was $273.88 \pm 24.93 \mathrm{mg} / \mathrm{L}$, and removal efficiency of COD was $89.05 \%$. Relative growth rate (RGR) of plants was $0.002 \pm 0.00$, and the number of living clumps was nine (50\%). The results showed that $50 \%$ of batik wastewater can be treated by Chrysopogon zizanioides L. in a hydroponic system.
\end{abstract}

Keywords: chromium, phytoremediation, water quality, Chrysopogon zizanioides L.

\section{Introduction}

Batik industry in Indonesia is growing rapidly. Based on data from the Ministry of Industry in 2015, the batik industry's production and average export value reached $\$ 178$ million USD - an increase of $25.7 \%$ from the year before. However, along with its growth, the industry also experienced an increase in wastewater that brings forth environmental consequences. When batik wastewater is directly discharged into waters, it brings highly concentrated toxins into the water. A characteristic of batik wastewater [1] was depicted by its physical

*e-mail: jennyevry@gmail.com characteristics (color, odor, TSS, and temperature) and its chemical characteristics (organic and inorganic compounds, phenol, sulfur, $\mathrm{pH}$, heavy metals, ammonia, lipid, and oils). The dyes derived from the batik fabric washing process contain heavy metal. Metal originating from the fabric dyeing process is in the form of chromium. The presence of chromium in the water is found in two forms: trivalent chromium $\left(\mathrm{Cr}^{3+}\right)$ and hexavalent chromium $\left(\mathrm{Cr}^{6+}\right) \cdot \mathrm{Cr}^{6+}$ is more toxic than $\mathrm{Cr}^{3+}$ because its ion is difficult to decompose [2]. Heavy metals contained in the batik waste are $\mathrm{Fe}, \mathrm{Cu}, \mathrm{Cd}$, and $\mathrm{Pb}$ [3]. Therefore, to minimize waste and to reduce the impact of pollution, it is necessary to employ a basic wastewater treatment before the dump. One measure of wastewater treatment is the use of a plant as an agent of phytoremediation. There are 
many advantage of phytoremediation, namely, flexibility of in-situ and ex-situ treatment, easy implementation, low cost, environmental friendliness, and effective contaminant reduction - primarily heavy metals in large quantities. This phytoremediation method may include artificial wetlands or retention ponds using crops due to rapid plant growth and the ability to accumulate toxic substances [4].

In the development, some researchers have applied the treatments of industrial waste, domestic waste, and aquaculture wastewater by using different species of plant such as water hyacinth [5], water cress [6], and Chrysopogon zizanioides L. [7-8]. Research on treating batik wastewater containing chromium metal has also been conducted by using Eichornia crassipes, Pistia stratiotes, and Hydrilla verticillata with decreasing percentages of $49.56 \%, 33.61 \%$, and $10.84 \%$, respectively [9]. Selection of these plants is associated with their abilities to remove heavy metals and other pollutants. Furthermore, the advantages of vegetation over the other method are its high tolerance range to the environment, and that it is generally easy to breed [10]. Plant species criteria suitable for phytoremediation is the high absorption level of organic and inorganic pollutants, growth adaptability in polluted water, controllability of the spread, and a strong ability to reduce contaminants while growing in various rough terrains and conditions [11]. Chrysopogon zizanioides L. does not require special growing requirements, grows well in extreme media, and has a massive root system [12]. Several studies on Vetiver (C.zizanioides L.) indicate that these plants provide good growth when planted on some types waste such as biogas wastewater and improve waste water quality [13], and can degrade trichloroethylene (TCE) from contaminated land by $98 \%$ for two ecotypes [14]. In addition, Chrysopogon zizanioides $\mathrm{L}$. is able to absorb soluble nutrients such as $\mathrm{N}$ and $\mathrm{P}$ as well as cations [15] and heavy metals, and it is also highly tolerant to herbicides and pesticides [16]. Moreover, a color change occurs in the oil palm wastewater treatment [17]. Chrysopogon zizanioides L. is also able to reduce chromium levels [18]. The many benefits of Chrysopogon zizanioides L. encourage its application in the research of batik wastewater management.

\section{Materials and Methods}

This research was performed in May-July 2016. Wastewater samples were collected from the batik industry in the Cikarang Jababeka industrial area. Analysis of water quality was conducted in the testing and environmental laboratories of Polytechnic AKA Bogor.

Chrysopogon zizanioides L. was used as a phytoremediator plant. The treatments were concentrations of wastewater, namely control PL0 (no waste), PL50 (50\% waste $+50 \%$ water), PL75 (75\% waste $+25 \%$ water) and PL100 (100\% waste). Each treatment was in triplicate. A hydrophonic system was applied when planting Chrysopogon zizanioides L. [19]. Water temperature in the tub and light intensity at each treatment were adjusted homogeneously. The study was carried out in an open space with a roof.

Chrysopogon zizanioides L. selection was based on the same age. Crops were washed with water and stored in a plastic tub containing $25 \mathrm{~L}$ of water and an A B mix nutrient solution. Each tub consisted of six pots, each containing three clumps of plant. The plants were acclimatized for three weeks using a floating system where the roots were submerged in water [15].

\section{Preparation of Wastewater}

Wastewater was spiked with $2 \mathrm{ppm}$ chromium. The standart usage of chromium based on Regulation of Minister of Environment No.5/2014 on waste of batik and textile industry amounted to $0.5-1 \mathrm{ppm} \mathrm{Cr}$. The 2 ppm spiked concentration is intentionally done above the standard to determine the ability of plants to absorb chromium. A total of $225 \mathrm{~L}$ wastewater was added with $0.45 \mathrm{~g}$ of potassium dichromate. Calculation of treatment concentration follows the dilution formula: $\mathrm{V} 1 \mathrm{~N} 1=\mathrm{V} 2 \mathrm{~N} 2$.

\section{Planting of Chrysopogon zizanioides L.}

Chrysopogon zizanioides L. which had been acclimatized and had good growth, was adjusted to $10 \mathrm{~cm}$ total length, then stored in $40 \times 30 \times 25 \mathrm{~cm}$ of plastic tubs. As many as 14 containers were prepared and filled with 251 of batik wastewater. Furthermore, six pots were floated in a plastic tub with styrofoam as a holder. Each pot was filled with three clumps of Chrysopogon zizanioides L., and the observation lasted 56 days based on the research of [20].

\section{Water Quality Measurement}

Water quality observed included temperature, total suspended solids (TSS), $\mathrm{pH}$, total ammonia, BOD, COD, and total chromium. Sampling was performed every week. Samples were analyzed using the APHA method (2012). Metals reduction calculation follows the formula [21]:

$$
\mathrm{R}=\left(\frac{\mathrm{I}-\mathrm{F}}{\mathrm{I}}\right)_{\mathrm{X}} 100 \%
$$

...where $\mathrm{R}$ is removal efficiency, $\mathrm{I}$ is the initial concentration of metals, and $\mathrm{F}$ is the final concentration of metal.

\section{Growth of Chrysopogon zizanioides L.}

Plant height, number of tillers, and the number of living clumps of Vetiver were observed. Relative growth rate (RGR) was calculated by the following equation [22]: 
Table 1. Characteristics of inlet of batik wastewater

\begin{tabular}{|c|c|c|c|}
\hline Parameter & Unit & $\begin{array}{c}\text { Batik/ } \\
\text { Textiles } \\
\text { wastewater }\end{array}$ & $\begin{array}{c}\text { Regulation } \\
\text { of the Minister } \\
\text { of Environment } \\
\text { No 5, 2014 }\end{array}$ \\
\hline Temperature & ${ }^{\circ} \mathrm{C}$ & 30 & ---- \\
\hline $\mathrm{TSS}$ & $\mathrm{mg} / \mathrm{L}$ & 268 & 50 \\
\hline $\mathrm{pH}$ & - & 9.8 & $6.0-9.0$ \\
\hline Total ammonia & $\mathrm{mg} / \mathrm{L}$ & 1.27 & 8.0 \\
\hline $\mathrm{BOD}$ & $\mathrm{mg} / \mathrm{L}$ & 966.83 & 60 \\
\hline $\mathrm{COD}$ & $\mathrm{mg} / \mathrm{L}$ & 2900.48 & 150 \\
\hline Total Chrom & $\mathrm{mg} / \mathrm{L}$ & 2.34 (spike) & 1.0 \\
\hline
\end{tabular}

$$
\mathrm{RGR}=\left(\frac{\ln \mathrm{W}_{t}-\ln \mathrm{W}_{0}}{\mathrm{t}-\mathrm{t}_{0}}\right)
$$

...where $\mathrm{W}_{0}$ and $\mathrm{W}_{\mathrm{t}}$ are the initial wet weight $(\mathrm{g})$ and wet weights at time- $\mathrm{t}(\mathrm{g})$, while $\mathrm{t}_{0}$ and $\mathrm{t}$ are the initial observation time (day) and observation at time-t (days).

Data were statistically analyzed using analysis of variance (ANOVA) and the Duncan test $(p<0.05)$. Analyses were performed using the SAS.9.1 program.

\section{Results and Discussion}

\section{Water Quality}

Batik wastewater quality before treatment is presented in Table 1. Water quality parameters such as temperature, TSS, pH, BOD, COD, total chromium, and total ammonia in each treatment are presented in Table 2. The average temperature in each treatment was relatively not much different and ranged $28.10-29.00^{\circ} \mathrm{C}$. Treatments of PL0, PL50, and PL75 had no significant differences $(\mathrm{p}<0.05)$, while PL100 had significant differences compared to PL0, PL50, and PL75 $(\mathrm{p}<0.05)$.

During the observation period, $\mathrm{pH}$ ranged from 8.13 to 9.34. Plants demonstrated better absorption ability at $\mathrm{pH}$ 6-9. The more alkaline the $\mathrm{pH}$, the effectiveness of absorption tends to be decreased [23]. TSS ranged 433.79-2,949.08 mg/L, in which the higher the effluent concentration, the higher the turbidity. It can also occur due to the addition of $\mathrm{AB}$ mix, which causes turbidity in the waste in containers within the hydroponic system. The levels of total ammonia ranged $0.74-0.78 \mathrm{mg} / \mathrm{L}$ and had no significant difference at control PL0. BOD ranged 5.94-52.89 mg/L for each treatment. BOD of PL0 (control) was significantly different from that of PL50, PL75, and PL100. COD was in the range of 44.76 to $559.94 \mathrm{mg} / \mathrm{L}$ and differed significantly $(\mathrm{p}<0.05)$ in each treatment. Total chromium found in wastewater ranged 0.81-2.34 mg/L. Each treatment of PL0, PL50, PL75, and PL100 was shown to be significantly different $(\mathrm{p}<0.05)$. Chrysopogon zizanioides L. density was directly proportional to the absorption capability of contaminants. According to [24], the absorption of BOD and COD by $96 \%$ and $94 \%$ can be achieved by Chrysopogon zizanioides L. density by as much as 30 with observation time of four weeks.

\section{Growth of Chrysopogon zizanioides L.}

The growth of Chrysopogon zizanioides L. on various treatments can be seen in Table 3, which shows that the number of living clumps, plant height, and relative growth rate (RGR) on each treatment was not much different. The final wet weights in PL0 and PL50 were not much different and ranged from 16.20 to $16.30 \mathrm{~g}$, while PL75 and PL100 were different, ranging from 14.58 to 15.08 g (Fig. 1). These study results were smaller than other studies in which the average accumulations of biomass were $18.3 \mathrm{~g}$ and $18.9 \mathrm{~g}$. According to [25], at 50\% tapioca waste, Chrysopogon zizanioides L. could live with the dry biomass of $20.51 \mathrm{~g} /$ pot, and $15.58 \mathrm{~g} /$ pot could grow

Table 2 . Average water quality parameter at each treatment

\begin{tabular}{|c|c|c|c|c|c|}
\hline \multirow{2}{*}{ Parameters } & \multirow{2}{*}{ Unit } & \multicolumn{4}{|c|}{ Treatments } \\
\cline { 3 - 6 } & & PL0 & PL50 & PL75 & PL100 \\
\hline Temperature & ${ }^{\circ} \mathrm{C}$ & $28.56 \pm 0.20^{\mathrm{b}}$ & $28.54 \pm 0.15^{\mathrm{b}}$ & $28.58 \pm 0.18^{\mathrm{b}}$ & $28.72 \pm 0.24^{\mathrm{a}}$ \\
\hline $\mathrm{TSS}$ & $\mathrm{mg} / \mathrm{L}$ & $433.79 \pm 91.76^{\mathrm{d}}$ & $1424.04 \pm 166.62^{\mathrm{c}}$ & $2031.29 \pm 95.84^{\mathrm{b}}$ & $2949.08 \pm 117.12^{\mathrm{a}}$ \\
\hline $\mathrm{pH}$ & - & $8.13 \pm 0.76^{\mathrm{b}}$ & $9.21 \pm 0.08^{\mathrm{a}}$ & $9.28 \pm 0.10^{\mathrm{a}}$ & $9.34 \pm 0.11^{\mathrm{a}}$ \\
\hline Total ammonia & $\mathrm{mg} / \mathrm{L}$ & $0.07 \pm 0.04^{\mathrm{d}}$ & $0.74 \pm 0.28^{\mathrm{a}}$ & $0.89 \pm 0.20^{\mathrm{a}}$ & $0.78 \pm 0.62^{\mathrm{a}}$ \\
\hline BOD & $\mathrm{mg} / \mathrm{L}$ & $7.05 \pm 2.53^{\mathrm{c}}$ & $37.95 \pm 8.14^{\mathrm{b}}$ & $44.02 \pm 19.54^{\mathrm{ab}^{\mathrm{b}}}$ & $52.89 \pm 8.96^{\mathrm{a}}$ \\
\hline COD & $\mathrm{mg} / \mathrm{L}$ & $44.76 \pm 5.65^{\mathrm{d}}$ & $273.88 \pm 24.93^{\mathrm{c}}$ & $427.75 \pm 35.93^{\mathrm{b}}$ & $559.94 \pm 22.56^{\mathrm{a}}$ \\
\hline Total Chrom & $\mathrm{mg} / \mathrm{L}$ & $0.01 \pm 0.02^{\mathrm{d}}$ & $0.81 \pm 0.06^{\mathrm{c}}$ & $1.39 \pm 0.15^{\mathrm{b}}$ & $2.34 \pm 0.07^{\mathrm{a}}$ \\
\hline
\end{tabular}

Description: PL0 = Vetiver Control (C. zizanioides) without waste, PL50 = Vetiver in 50\% water $+50 \%$ water, PL75 = Vetiver in $75 \%$ wastes $+25 \%$ water, PL100 = Vetiver in $100 \%$ waste;Different superscript shows significantly different $(p<0.05)$. 
Table 3.The growth of plants in each treatment

\begin{tabular}{|c|c|c|c|c|c|}
\hline \multirow{2}{*}{ Parameter } & \multirow{2}{*}{ Unit } & \multicolumn{4}{|c|}{ Treatment } \\
\cline { 3 - 6 } & & PL0 & PL50 & PL75 & PL100 \\
\hline Initial weight (Wo) & $\mathrm{g}$ & $14.54 \pm 0.07^{\mathrm{a}}$ & $14.57 \pm 0.19^{\mathrm{a}}$ & $14.48 \pm 0.03^{\mathrm{b}}$ & $14.45 \pm 0.11^{\mathrm{b}}$ \\
\hline Final weight (Wt) & $\mathrm{g}$ & $16.39 \pm 0.51^{\mathrm{a}}$ & $16.35 \pm 0.47^{\mathrm{a}}$ & $15.08 \pm 0.52^{\mathrm{b}}$ & $14.51 \pm 0.09^{\mathrm{b}}$ \\
\hline Number of living clumps & clumps & $11(61 \%)^{\mathrm{a}}$ & $9(50 \%)^{\mathrm{a}}$ & $6(35 \%)^{\mathrm{b}}$ & $4(20 \%)^{\mathrm{b}}$ \\
\hline Height growth every week & $\mathrm{cm} /$ day & $0.032 \pm 0.001^{\mathrm{a}}$ & $0.03 \pm 0.004^{\mathrm{a}}$ & $0.022 \pm 0.009^{\mathrm{b}}$ & $0.018 \pm 0.005^{\mathrm{b}}$ \\
\hline Relative Growth Rate (RGR) & $\mathrm{g} /$ day & $0.002 \pm 0.00^{\mathrm{a}}$ & $0.002 \pm 0.001^{\mathrm{a}}$ & $0.001 \pm 0.00 \mathrm{~b}$ & $0.0004 \pm 0.00^{\mathrm{b}}$ \\
\hline
\end{tabular}

Description: PL0 $=$ Vetiver (C. zizanioides) without waste, PL50 = Vetiver in 50\% wastes $+50 \%$ water, PL $75=$ Vetiver in $75 \%$ wastes $+25 \%$ water, PL100 $=$ Vetiver in $100 \%$ waste

at $100 \%$ tapioca waste. Research of [26] indicated that growth in PL50 showed RGR values approaching PL0 and was greater than that of PL75 and PL100. This is likely caused by the concentration of Cr in PL0 lower than the concentration of Cr in the PL75 and PL100. Therefore, it can be a cause for the obstruction of plant growth.

The number of clumps in PL50 was nine, which is no different from the number of clumps in PL0 (control), yet the values in PL50 and PL0 were greater than that in PL75 and PL100 (six and four clumps), respectively. The number of living clumps is inversely related to the waste concentration level where the greater waste concentration would produce fewer living clumps. Height growth and relative growth (RGR) of PL50 were higher than that of PL75 and PL100 (Fig. 4). These results are consistent with previous research using $50 \%$ tapioca waste, and Chrysopogon zizanioides L. growth was higher than other levels of tapioca waste $(0,60,70,80,90$, and $100 \%)$ [26]. The same results were also shown by [27] on coconut husk waste and research of [24] using secondary palm oil waste, as well as automobile waste with a wetlands system [28]. PL50 had average plant height of $0.03 \pm 0.004$ $\mathrm{cm} /$ day and was not much different from the PL0

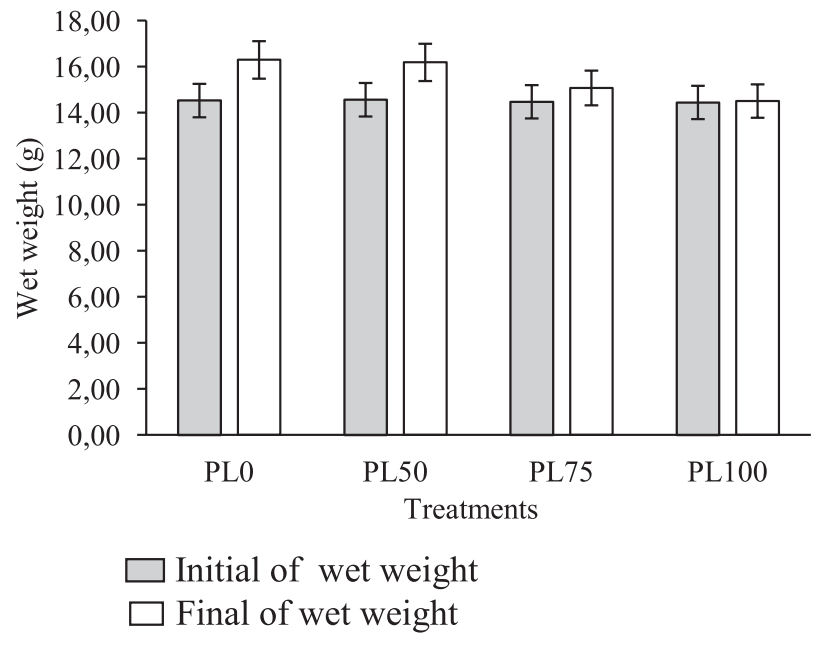

Fig. 1. Weights of Chrysopogon zizanioides L.: initial wet weight, final wet weight. (control) of $0.032 \pm 0.001 \mathrm{~cm} / \mathrm{day}$, while PL75 and PL100 had $0.022 \pm 0.009$ and $0.018 \pm 0.005 \mathrm{~cm} /$ day, respectively (Fig. 3).

Plant growth is generally influenced by external and internal factors. External factors include air temperature, light, and humidity. Meanwhile, internal factors include heredity and physiology of the individual itself. Chrysopogon zizanioides L. is a fast-growing grass with a large and complex root system. It is able to grow in difficult conditions, and it has unique morphological and physiological characteristics, as well as a very high tolerance to heavy metals and adverse conditions [29], and high tolerance toward extreme climatic conditions such as drought, extreme temperatures, and acid and alkaline $\mathrm{pH}$. Factors that control plant uptake were the age of plants, seasonal variations, and climatic conditions [30]. Chrysopogon zizanioides L. can accumulate heavy metals in roots, making it suitable for phytostabilization and phytoextraction with the addition of chelating agents [31]. One of the distinctive characteristics of Chrysopogon zizanioides L. is its ability to form a thick hedge when planted close together, and it can stand upright at a depth of $0.6 \mathrm{~m}$ in water flow, forming a barrier that can impede water runoff and act as a very effective filter for capturing sediment and chemicals [29].

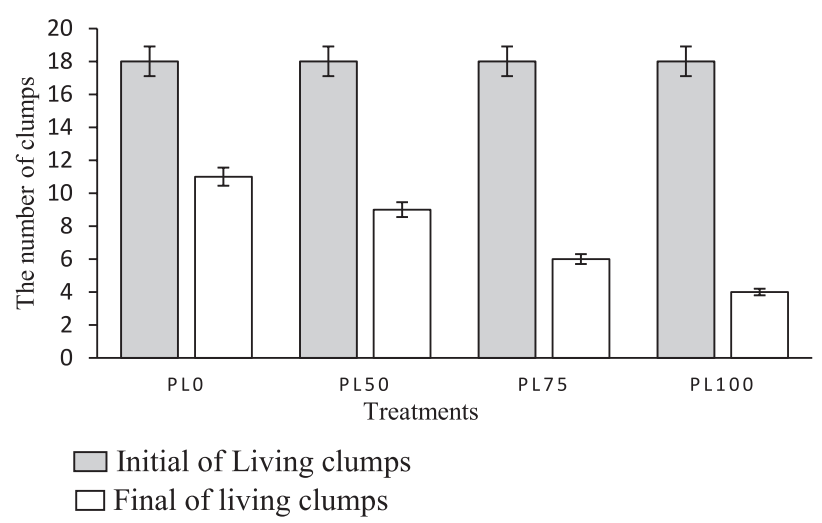

Fig. 2. Number of living clumps: initial living clumps, final living clumps. 


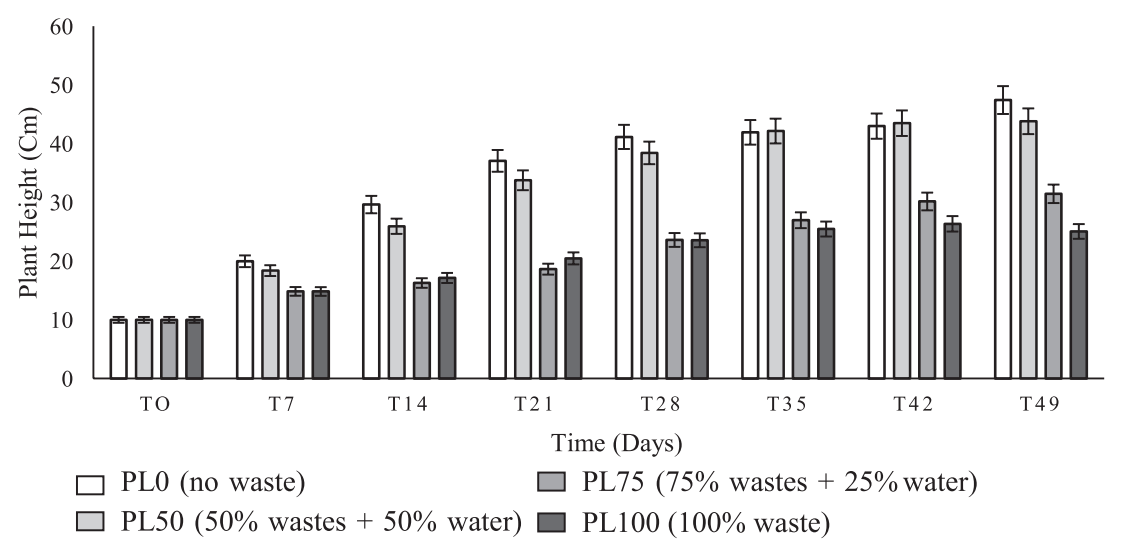

Fig. 3. Plant height growth: PL0 (no waste), PL50 (50\% wastes $+50 \%$ water), and PL 75 ( $75 \%$ wastes $+25 \%$ water, PL 100 ( $100 \%$ waste).

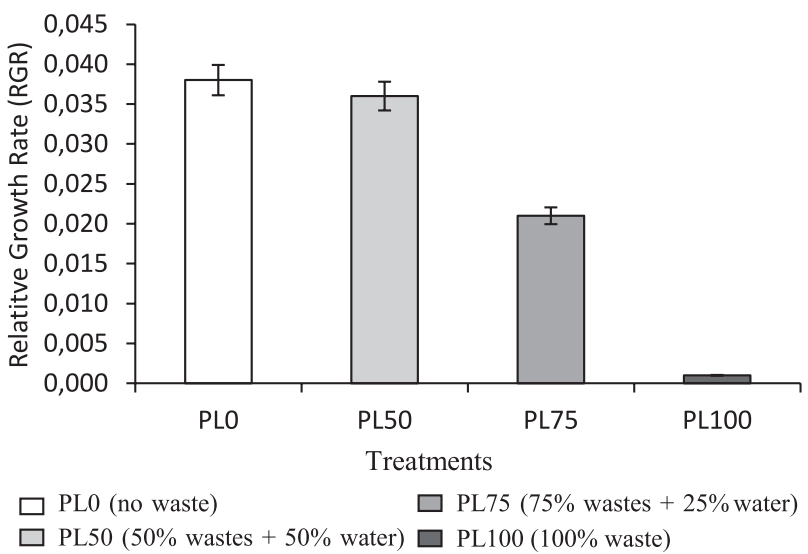

Fig. 4. Relative growth rate (RGR): PL0 (no waste), PL50 (50\% wastes $+50 \%$ water), and PL75 ( $75 \%$ wastes $+25 \%$ water, PL100 (100\% waste).

Height growth of Vetiver can reach $134 \mathrm{~cm}$, root length of $24.62 \mathrm{~cm}$, and a survival rate of $95.5 \%$ in textile waste [32]. According to [33], although this condition indicates that every plant is conditioned equally in terms of age, height, and weight, each plant has a different ability to adapt to the new environment. Related to the total accumulated metals in both the roots and in the leaves, Chrysopogon zizanioides $\mathrm{L}$. absorb more $\mathrm{Cu}$ than $\mathrm{Cd}$. Increasing the age and the biomass of Chrysopogon zizanioides L. will enhance root development, and therefore the absorption rate of nutrients and photosynthesis will increase, which means an increase in the potential for waste degradation [25].

\section{Chromium in Wastewater}

Cr decline dramatically occurred in PL50 from week 0 to week 1 (Table 4). The treatment of PL50 had significant differences with PL75 and PL100 $(\mathrm{p}<0.05)$. Based on the time, week 0 was significantly different from weeks 2,3 , and 5 , and also significantly different from weeks 6 and $7(p<0.05)$. The concentration in PL50 in the $3^{\text {rd }}$ week until the 5 th week had no significant decline. According to [23], Chrysopogon zizanioides L. can reduce $\mathrm{Cr}$ concentration from $5 \mathrm{mg} / \mathrm{L}$ to $1.125 \mathrm{mg} / \mathrm{L}$, and even higher than the results of this study, as well as result of Rodriguez [18], the treatment of contaminated sludge could absorb $30 \% \mathrm{Cr}$, which is less than the result of this study of $40.29 \%$ (Table 6 ).

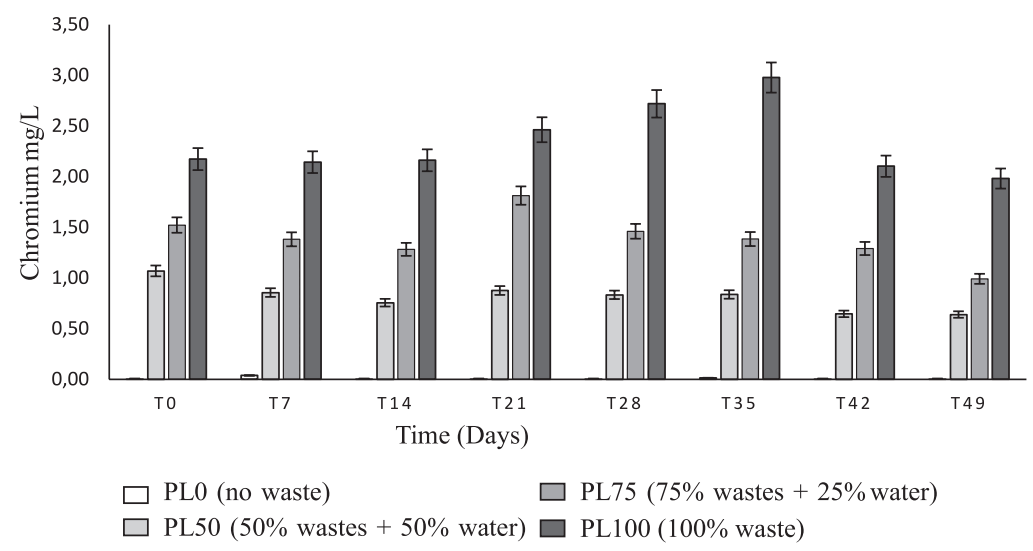

Fig. 5. Chromium concentration fluctuations during the experiment: PL0 (no waste), PL50 (50\% wastes + 50\% water), PL75 (75\% wastes $+25 \%$ water, and PL100 (100\% waste). 
Table 4. Cr concentrations in the water.

\begin{tabular}{|c|c|c|c|}
\hline Period & \multicolumn{3}{|c|}{ Concentrations mg/L } \\
\hline (Weeks) $^{\text {PL50 }}$ & PL75 $^{\mathrm{b}}$ & PL100 $^{\mathrm{a}}$ \\
\hline $\mathrm{T}^{\mathrm{ab}}$ & $1.07 \pm 0.059$ & $1.52 \pm 0.057$ & $2.17 \pm 0.053$ \\
\hline $\mathrm{T}^{\mathrm{bc}}$ & $0.85 \pm 0.037$ & $1.38 \pm 0.017$ & $2.14 \pm 0.011$ \\
\hline $\mathrm{T}^{\mathrm{c}}$ & $0.75 \pm 0.033$ & $1.28 \pm 0.171$ & $2.16 \pm 0.085$ \\
\hline $\mathrm{T}^{\mathrm{a}}$ & $0.88 \pm 0.031$ & $1.81 \pm 0.615$ & $2.46 \pm 0.014$ \\
\hline $\mathrm{T}^{\mathrm{a}}$ & $0.83 \pm 0.099$ & $1.46 \pm 0.082$ & $2.72 \pm 0.063$ \\
\hline $\mathrm{T}^{\mathrm{a}}$ & $0.84 \pm 0.019$ & $1.38 \pm 0.009$ & $2.98 \pm 0.130$ \\
\hline $\mathrm{T}^{\mathrm{c}}{ }^{\mathrm{a}}$ & $0.64 \pm 0.138$ & $1.29 \pm 0.118$ & $2.10 \pm 0.120$ \\
\hline $\mathrm{T}^{\mathrm{d}}$ & $0.64 \pm 0.099$ & $0.99 \pm 0.104$ & $1.98 \pm 0.069$ \\
\hline
\end{tabular}

Description: Different superscript shows significantly different effect among treatments $(\mathrm{p}<0.05)$.

Table 5. Accumulation of $\mathrm{Cr}\left(\mathrm{mg} \mathrm{kg}^{-1}\right)$ in Chrysopogon zizanioides $\mathrm{L}$.

\begin{tabular}{|c|c|c|c|c|}
\hline \multirow{2}{*}{ Parameter } & \multicolumn{4}{|c|}{ Concentration $\left(\mathrm{mg} \mathrm{L}^{-1}\right)$} \\
\cline { 2 - 5 } & PL0 & PL50 & PL75 & PL100 \\
\hline Root & 0.45 & 18.28 & 27.17 & 33.52 \\
\hline Leaf & 0.88 & 1.27 & 0.96 & 0.86 \\
\hline Total accumulation & 1.33 & 19.56 & 28.12 & 34.37 \\
\hline
\end{tabular}

Description: PL0 $=$ Vetiver Control (C. zizanioides) without waste, PL50 $=$ Vetiver in $50 \%$ wastes $+50 \%$ water, PL75 $=$ Vetiver in $75 \%$ wastes $+25 \%$ water, PL100 $=$ Vetiver in $100 \%$ waste

Table 6. Removal efficiency of chromium in wastewater.

\begin{tabular}{|c|c|c|c|c|}
\hline \multirow{2}{*}{ Treatment } & \multirow{2}{*}{$\begin{array}{c}\text { Initial } \\
\text { Concen- } \\
\text { tration } \\
\mathrm{mg} / \mathrm{L}\end{array}$} & \multicolumn{2}{|c|}{ Concentration $\mathrm{mg} / \mathrm{L}$} & \multirow{2}{*}{$\begin{array}{c}\text { Efficiency } \\
(\%)\end{array}$} \\
\hline & & Final & Decreasing & \\
\hline PL50 & 1.069 & 0.638 & 0.431 & 40.29 \\
\hline PL75 & 1.521 & 0.991 & 0.530 & 34.87 \\
\hline PL100 & 2.172 & 1.980 & 0.192 & 8.85 \\
\hline
\end{tabular}

Description: PL50 $=$ Vetiver in 50\% wastes $+50 \%$ water, PL75 $=$ Vetiver in $75 \%$ wastes $+25 \%$ water, PL100 $=$ Vetiver in $100 \%$ waste
Chromium Accumulation in Plants

Chrysopogon zizanioides L. can accumulate $\mathrm{Cr}$ in large quantities. The $\mathrm{Cr}$ toxicity threshold for Chrysopogon zizanioides $\mathrm{L}$. ranged from $5-18 \mathrm{mg} / \mathrm{kg}$ [30]. Concentrations of $\mathrm{Cr}$ in roots ranged 18.28-33.52 $\mathrm{mg} / \mathrm{kg}$, and in leaves ranged $0.86-1.27 \mathrm{mg} / \mathrm{kg}$ (Table 6). Accumulation of $\mathrm{Cr}$ in the roots was higher than that in the leaves because the root has a high cation exchange capacity to absorb the $\mathrm{Cr}$ in the wastewater, which is then transmitted to the leaves [34]. Chrysopogon zizanioides L. can absorb metals such as $\mathrm{Mn}, \mathrm{Fe}, \mathrm{Cu}, \mathrm{Zn}$, and $\mathrm{Pb}$ from industrial waste [35] and TNT organic waste [36]. Chrysopogon zizanioides L. can be grown on waste containing cadmium at concentrations of 1-7.5 ppm, and it does not produce toxicity [37]. Chrysopogon zizanioides $\mathrm{L}$. absorption of $\mathrm{Cu}$ was greater than that of $\mathrm{Cd}$ [33].

An increase in the number of Chrysopogon zizanioides L./pot totally increases the absorption of $\mathrm{Cr}$, yet the absorption continuously decreases with the lower number of Chrysopogon zizanioides L. or clumps [38]. The height growth of plants was not much different between the control and PL50, whereas the growth of PL75 and PL100 were different from PL0 and PL50. The increase in number of Chrysopogon zizanioides L./pots increases the absorption of $\mathrm{Cr}$ for any number of plants per clump. The absorption rate of $37.01 \%$ was observed in three clumps of Chrysopogon zizanioides L./pot [38]. This suggests that Chrysopogon zizanioides L. has the ability to absorb Cr. This result was lower than the results obtained in this study (40.29\%). [24] found that $\mathrm{Cr}$ absorption efficiency reached $77-78 \%$. Chrysopogon zizanioides $\mathrm{L}$. is also able to reduce the levels of $\mathrm{Cr}$ up to $30 \%$ in sludge containing chromium of $21,000 \mathrm{mg} / \mathrm{kg}$ to be $13,529 \mathrm{mg} / \mathrm{kg}$ [38]. The Chrysopogon zizanioides L. can also grow well in fish cultivation media by absorbing and using nutrients in water for its growth process [39].

\section{Conclusion}

The growth of Chrysopogon zizanioides L. in PL50 (50\% wastewater treatment) was more optimal than that of in PL75 and PL100. Absorption of Cr reached 40.29\%. It is suggested to conduct further research using a much higher number of clumps in order to make more optimal metal absorption.

Table 7. Removal Efficiency of BOD and COD

\begin{tabular}{|c|c|c|c|c|c|c|c|c|c|c|}
\hline \multirow{2}{*}{$\begin{array}{l}\text { Para } \\
\text { meter }\end{array}$} & \multirow{2}{*}{ Unit } & \multicolumn{2}{|c|}{ PL50 } & \multirow{2}{*}{$\begin{array}{c}\text { Efficiency } \\
\%\end{array}$} & \multicolumn{2}{|c|}{ PL75 } & \multirow{2}{*}{ Efficiency \% } & \multicolumn{2}{|c|}{ PL100 } & \multirow{2}{*}{$\begin{array}{c}\text { Efficiency } \\
\%\end{array}$} \\
\hline & & Initial & Final & & Initial & Final & & Initial & Final & \\
\hline BOD & $\mathrm{mg} / \mathrm{L}$ & 117.28 & 1.80 & 98.47 & 134.77 & 4.42 & 96.72 & 164.21 & 3.68 & 97.76 \\
\hline COD & $\mathrm{mg} / \mathrm{L}$ & 773.50 & 84.72 & 89.05 & 806.00 & 60.89 & 60.89 & 788.64 & 95.18 & 88.65 \\
\hline
\end{tabular}




\section{Acknowledgements}

The authors gratefully acknowledge the environmental test laboratory and Polytechnic AKA Bogor for its support and facilities for our research.

\section{References}

1. MULJADI. Efficiency of industrial wastewater plant batik prints with methods of chemical physics and biology against decrease pollutant parameters (bod, cod dan heavy metal). Ekuilibrium. 8 (1), 7, 2009.

2. ACKERLEY D.F., GONZALES C.F., PARK C.H., BLAKE R., KEYHAN M., MARTIN A.Chromat reducing properties of soluble flavoprotein from Pseudomonas putida and Escherichia coli. Applied and Environmental Biology. 70 (2), 873, 2004.

3. AGUSTINA T.E., NURISMAN E., PRASETYOWATI, HARYANI N., CHUNDARI L., NOVISA A., KRISTINA O. Wastewater treatment dyes synthesis using fenton reagent. Palembang:Proceedings of the National Seminar AvoER $3^{\text {rd }} .2011$.

4. PRIYA E.S., SELVAN P.S. Water hyacinth (Eichhornia crassipes) - An efficient and economic adsorbent for textile effluent treatment - A review. Arabian Journal of Chemistry. 2014.

5. VALIPOUR A., RAMAN V.K., YOUNG H.A. Effectiveness of domestic wastewater treatment using a bio-hedge water hyacinth wetland system.Water. 7, 329, 2015.

6. LU Q., HE Z.L., GRAETZ D.A., STOFFELLA P.J., YANG $X$. Phytoremediation to remove nutrients and improve eutrophic stormwaters using water lettuce (Pistia stratiotes L.).Environ. Sci. Poll. Res.17, 84, 2010.

7. SYAFRUDIN R. Artificial wetland wastewater treatment system as vaname shrimp culture (Litopenaeus vannamei) at mesohaline conditions. Bogor Agricultural University 2015.

8. DELIS P.C., EFFENDI H., KRISANTI M., HARIYADI S.Treatment of aquaculture wastewater using Vetiveria zizanioides (Liliopsida, Poaceae). AACL. 8, 4, 2015.

9. PUSPITAU R., SIREGAR A.S., HIDAYATI N.V. Ability of water plants as agents phytoremediator of heavy metal chromium $(\mathrm{Cr})$ contained in the liquid waste of batik. Berkala Perikanan Terubuk. 39 (1), 58, 2011.

10. GUPTA P., ROY S., MAHINDRAKAR A.B. Treatment of water using water hyacinth, water lettuce and vetiver grass - a review. Resources and Environment. 2 (5), 202, 2012.

11. TRUONG P. Research and development of the vetiver system for treatment of polluted water and contaminated land. India: TVN India 1st Workshop Proceedings. 60, 2008.

12. TRUONG P., HART B. Vetiver system for wastewater treatment. Technical Bulletin no. 21. Bangkok (TH): Pacific Rim Vetiver Network. Office. 2001.

13. YEBOAH S.A., ALLOTEY A.N.M., BINEYE. Purification of industrial wastewater with vetiver grasses (Vetiveria zizanioides): The Case of Food and Beverages Wastewater In Ghana. Asian Journal of Basic And Applied Science. 2, 2313, 2015.

14. JANNGAM J., ANURAKPONGSATORN P., SATAPANAJARU T., TECHAPINYAWAT S. Phytoremediation: vetiver grass in remediation of soil contaminated with trichloroethylene. Sci. J. UBU. 1 (2), 52, 2010.
15. DARAJEH N., IDRIS A., TRUONG P., AZIZA A., BAKAR R.A., CHEMAN H. Phytoremediation potential of vetiver system technology for improving the quality of palm oil mill effluent.Advance in Materials Science and Engineering. 2014 Article ID 683579, 10, 2014.

16. TRUONG P.N., FOONG Y.K., GUTHRIE M,. HUNG Y.T. Phytoremediation of heavy metal contaminated soils and water using vetiver grass. Environ. Engineer. 11, 233, 2010.

17. BEDEWI A.K.The potential of vetiver grass for wastewater treatment. Haramaya University. 2010.

18. RODRIQUEZ D.T., CUMANA A., TOREALBA O., POSADA D. Use of vetiver for the fitoremediation of chromiun in residual sludges in a tennery. Revista Mexicana de Ciencias Agrícolas. 1, 175, 2010.

19. BOONSONG K., CHANSIRI M. Domestic wastewater treatment using vetiver grass cultivated with floating platform technique. AU J.T. 12 (2), 73, 2008.

20. JAYASHREE S., RATHINAMALA J., LAKSHMANA P. Determination of heavy metal removal efficiency of Chrysopogon zizanioides (vetiver) using textile wastewater contaminated soil. J. Environ. Sci. Technol. 4 (5), 543, 2011.

21. KHAN S., AHMAD I., SHAH M.T., REHMAN S.H., KHALIQ A.Use of constructed wetland for the removal of heavy metals from industrial wastewater. J. Environ. Manage. 90, 3451, 2009.

22. MITCHELL D.S. Aquatic vegetation and its use and control. France: Unesco. 135 p., 1974.

23. SINGH V., THAKUR T., MANDAL P. Removal of lead and chromium from synthetic wastewater using Vetiveria zizanioides. Article in Clean - Soil air water. 42 (9999), 1, 2014.

24. DARAJEH N., IDRIS A., MASOUMI H.R.F., NOURANI A., TRUONG P., SAIRINA. Modelling BOD and COD removal from palm oil mill secondary effluent in floating wetland by Chrysopogon zizanioides (L.) using response surface methodology. J. Environ. Manage. 181, 343, 2016.

25. MUDHIRIZA T., F MAPANDA F., MVUMI B.M., WUTA M.Removal of nutrient and heavy metal loads from sewage effluent using vetiver grass, Chrysopogon zizanioides (L.) Roberty. Water SA. African Journals online. 41, 4, 2015.

26. INDRAYATIE E.R., UTOMO W.H., HANDAYANTO E., ANDERSON C.W.N. The use of vetiver (Vetiveria zizanioides $\mathrm{L}$.) for the remediation of wastewater discharged from tapioca factories. J. Environ and Waste Manage. 12 (1), 1,2013

27. GIRIJA N., PILLAI S.S., KOSHY M. Potential of vetiver for phytoremediation of waste in retting area.The Ecoscan. 1, 267, 2013.

28. DHANYA G., JAYAD. Pollutant removal in wastewater by vetiver grass in constructed wetland system. Int. J. Engineer. 2, 2278, 2013.

29. TROUNG P., VAN T.T., PINNERS E. Vetiver system applications technical reference manual. The vetiver network international. 127p, 2011.

30. SUELEE A.L. Phytoremediation potential of vetiver grass (Vetiveria zizanioides) for water contaminated with selected heavy metal.Department of Environmental Science Faculty of Environmental Studies Universiti Putra Malaysia. 2015.

31. DANH L.T.,TRUONG P., MAMMUCARI R.,TRAN T., FOSTER N.Vetiver grass, Vetiveria zizanioides: A choice plant for phytoremediation of heavy metals and organic wastes. Int. J. of Phytoremediation. 11, 644, 2009.

32. CHAROENLAR P.K., SURAKUL K., WINITKHETKAMNOUN P., KANTHUPTHIM P., PANBUMRUNG P., UDORN S. Textile wastewater 
treatment using vetiver grass cultivated with floating platform technique. 10 (1), 51, 2016.

33. ARYANI D.Utilization of vetiver grass (Chrysopogon zizanioides L.) in remediation process of heavy metal cadmium (Cd) and copper (Cu).Bogor Agricultural University. 2015

34. KADLEC R.H., KNIGHT R.L. Treatment wetlands. Boca Raton, Florida CRC Press/Lewis Publishers. 1996.

35. ROONGTANAKIAT N., TANGRUANGKIAT S., MEESAT R. Utilization of Vetiver Grass (Vetiveria zizanioides) for removal of heavy metals from industrial wastewaters. Sci. Asia. 33, 397, 2007.

36. MAKRIS K.C., KABINDRA M., SHAKYA, DATTA, R., SARKAR D., PACHANOOR D. High uptake of 2,4,6-trinitrotoluene by vetiver grass potential for phytoremediation. Environ. Poll. 146, 1, 2007.
37. AIBIBU N., LIUY., ZENG G., WANGA X., CHEN B., SONG H., XUA L. Cadmium accumulation in Vetiveria zizanioides and its effects on growth, physiological and biochemical characters. Bioresource Technology. 10, 6297, 2010.

38. ZUBAIR A., SELINTUNG M., SAMANG L., USMAN H. Experimental study of vetiver phytoremediation on compost clay with chromium $(\mathrm{Cr})$ and cadmium $(\mathrm{Cd})$ contaminant. Int. J. Engineer and Sci. Appl. 2, 2406, 2015.

39. EFFENDI H., DELIS P.C., KRISANTI M., HARIYADI S. The performance of nile tilapia (Oreochromis niloticus) and Vetiver Grass (Vetiveria zizanioides) concurrently cultivated in aquaponic system. Advances in Env. Bio. 